\title{
GANGLION AND HAEMANGIOMA AS A CAUSE OF PLANTAR NEURITIS
}

By A. M. Wiley, M.B.E., M.Ch., F.R.C.S.

Nuffield Orthopaedic Centre, Oxford

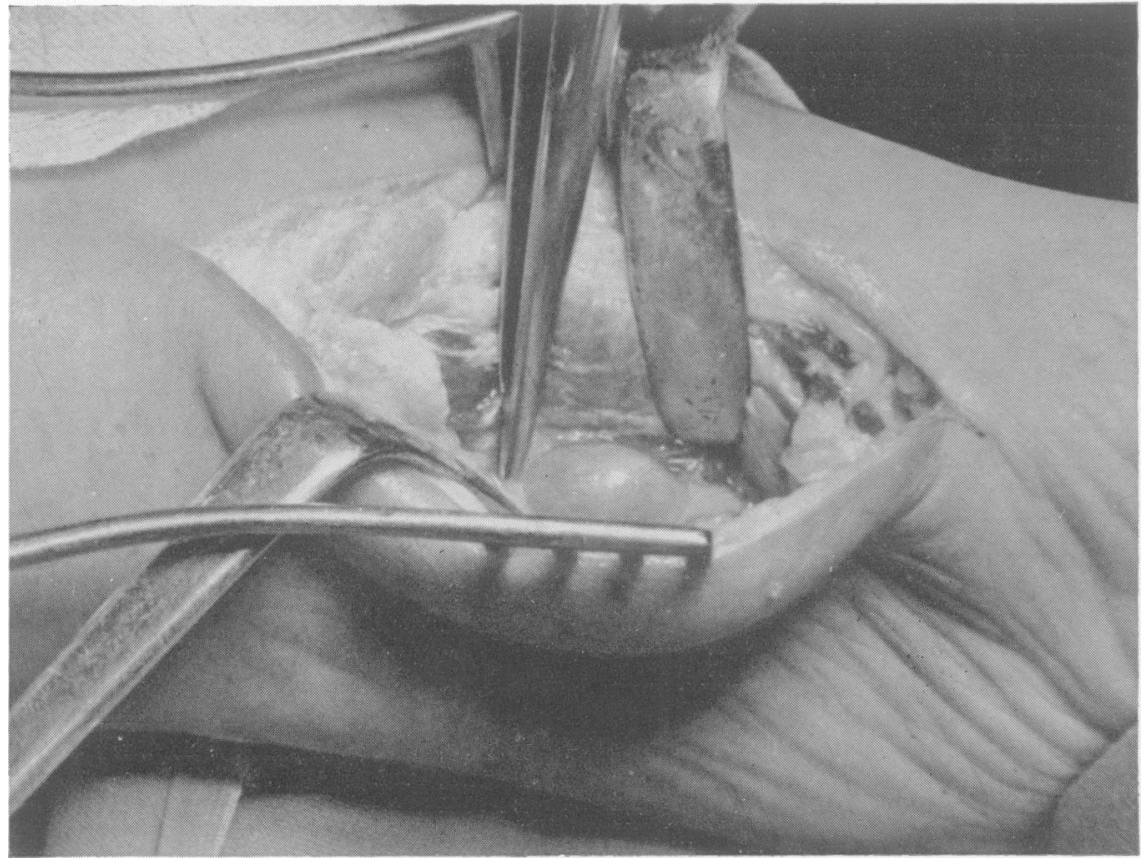

Fig.r.-Case 2. Operative findings. An angioma lying alongside the medial plantar nerve.

Pressure due to a simple tumour has to be considered as a cause of isolated peripheral neuritis particularly in the neighbourhood of tendons and joints. Prochazka (1947) published what is apparently the first report of a patient suffering from ulnar neuritis due to a ganglion. Seddon (1952) described three cases of his own and Brooks (1952) collected I3 from various centres. Nerve pressure due to ganglia has now been described at the wrist, the elbow, knee and ankle.

In the foot, neuritis due to a plantar neuroma situated between the metatarsal heads is a well recognised condition described in detail by Betts (I940) but I have been able to trace only one previous reference to plantar neuritis due to ganglion (Brooks, 1952), and to angioma (Berry, 1957).

\section{Case Reports \\ Number One}

Mrs. P.T., agcd 38. Three months before admission, while wearing bedroom slippers at home after leaving work, she suddenly developed a cramp in her right foot. Since then she had had cramps, aching and tingling in the outer part of the sole of her foot. Her symptoms were corıtinuous, and severe at night.

Examination. There was a very ill-defined swelling below the right medial malleolus which was palpable more than visible and disappeared beneath the flexor retinaculum, Pressure here 
caused paraesthesia in the sole. There was a broad area of anaesthesia on the sole, extending on to the third, fourth and fifth toes which showed early clawing; movements of the ankle joint, mid tarsal and transverse tarsal joints were normal and she could move her toes. An X-ray of the right ankle and foot was normal.

Operation. A sickle-shaped incision was made below the medial malleolus and after brief blunt dissection a bilocular ganglion was uncovered; it arose from the tendon sheath of the flexor pollicis longus. Over the ganglion was stretched the lateral plantar nerve. This was cleared away and the ganglion excised.

Immediately after the operation she declared her symptoms improved and subsequently gradually regained sensation in her foot. Pathological report on ganglion: "This is a collapsed cyst the wall of which is composed of synovial membrane in places showing much mucoid degeneration. There is some perivascular infiltration with lymphocytes and polymorphonuclear leucocytes.'

Number Two

Mrs. H.H., aged 49. She complained of pain in the sole of the left foot for years. Two years previously the foot was explored and some thickened plantar fascia excised, her symptoms being thereby temporarily relieved.

Exariination. She had sweaty feet, particularly so on the left side. There was an area of paraesthesia the size of a shilling in the sole of the left foot beneath the scar of the previous operation. An X-ray of the left foot showed a short first metatarsal.

Operation. A long incision was made parallel to the medial border of left foot. On retracting the plantar fascia laterally a cystic tumour, the size of an almond, was seen to lie close to the medial plantar nerve. The tumour was excised (Fig. I).

The wound healed soundly and she was discharged. Subsequently she was contacted and declared herself quite cured and 'able to walk anywhere without pain.'
Pathological report on tumour. 'A small smooth round tumour, $2 \times 1.5 \mathrm{~cm}$., which appeared firm until it was bisected when it was found to have a $\stackrel{\mathbb{Q}}{\varnothing}$ central cystic space containing pale yellow fluid. Microscopically the appearances are those of an angioma in which there are blood channels of considerably varying size, many being of the order of cavernous spaces while some are of capillary diameter. These channels are lined by endothelium and surrounding them there is considerable smooth muscle proliferation with, in many places, cells of the modified smooth muscle glomus type. The tumour apptars sharply circumscribed by a fibrous tissue capsule. Centrally there is a zone of cystic degeneration. The appearances are those of a haemangioma in which are seen glomus type of cells.'

\section{Comment}

Isolated peripheral neuritis in the extremities may be the pressure affcct of a lesion for which careful search is rewarding and removal iacile. Plantar neuritis may produce a typical deformity with digital clawing, the picture being more commonly seen in its counterpart, partial claw hand, due to ulnar neuritis.

My thanks are due to Mr. R. G. Taylo: and to Mr. J. D. Morgan for their permission to publish these cases which came under their care, and to Dr. Robb Smith and Dr. Dunnill for the pathoo logical reports.

\section{BIBLIOGRAPHY}

BETTS, L. O. (1940), Med. F. Aust., I, 514. BERRY, T. A. (1957), f. Bone ft Surg., 39b, 124. BROOKS, D. M. (1952), Ibid., 34b, 39r.

ELLIS, U. H. (1936), Brit. F. Surg., 24, 141.

HARTWELL, A. S. (I90I), 'Cystic tumour of Median Nerve,' Medical and Surgical fournal No. 24.

NISSEN, K. I. (1948), $\mathfrak{f}$. Bone $\mathfrak{f t}$ Surg., 3ob, 84.

PROCHAZKA, J. (1947), Sborn. Chir. Pohyb. Ustr., 15, 25 I.

SEDDON, H. J. (1952), f. Bone $¥$ t Surg., 34b, 386.

SULTAN, C. (1921), Zbl. Chir., 48, 963.

WADSTEIN, T. (1931), Acta orthop. scand., 2, 22 I.

WARREN, R. (1946), Ann. Surg., 124, 152.

ZAAR (1 926), Zbl. Chir., 53, 255.

\section{RUTHIN CASTLE, NORTH WALES}

A Clinic for the diagnosis and treatment of Internal Diseases (except Mental or Infectious Diseases). The Clinic is provided with a staff of doctors, technicians and nurses.

The surroundings are beautiful. The climate is mild. There is central heating throughout. The annual rainfall is $\mathbf{3 0 . 5}$ inches, that is less than the average for England.

The Fees are inclusive and vary according to the room occupied.

For particulars apply to THE SECRETARY, Ruthin Castle, North Wales. 